\title{
Flow Cytometric Methods in the Detection of Neonatal Infection
}

\author{
Christian Gille Thorsten W. Orlikowsky \\ Department of Neonatology, University Children's Hospital, University of Tübingen, Germany
}

\section{Key Words}

Sepsis - Macrophages · Neutrophils - T cells ·

CD markers · Cytomics · Cord blood

\section{Summary}

Background: Bacterial infection remains the main cause of neonatal morbidity and mortality. With clinical signs unspecific and little, its course is fulminant, and only early antibiotic therapy protects from death or major adverse sequelae. Methods: Conventional diagnostic tests have shortcomings and are only partly suitable to identify infected vs. non-infected newborns. There is a fast increasing demand for standardized flow cytometric techniques in the detection of neonatal infection which require minimal amounts of blood. Target cells are monocytes/macrophages, granulocytes and NK cells. Results: The choice of receptors and interpretation of results need to be done carefully: A variety of receptors are expressed differently, basally or upon cytokine-mediated regulation, in full- or preterm neonates than in adults, and their expression is influenced by perinatal confounders. Examples are HLA-DR, CD80, CD86, CD16, CD32 receptors on monocytes/macrophages. Flow cytometric measurement of CD11b and CD64 expression on phagocytes combined with cytokine (IL-6 or IL-8) or C-reactive protein measurement in plasma or whole blood have turned out to be most sensitive and specific markers for detecting early- and late-onset bacterial infection. Conclusion: To date, no flow cytometric marker or set of markers is sensitive and specific enough to allow neonatologists to withhold antibiotic treatment of a sick neonate who is suspected to be infected.

\section{Schlüsselwörter}

Neugeborenensepsis · Makrophagen · Neutrophile ·

T-Zelle · CD-Marker · Zytomik · Nabelschnurblut

\section{Zusammenfassung}

Hintergrund: Bakterielle Infektionen sind weltweit die Hauptursache neonataler Morbidität und Mortalität. Bei fulminantem Verlauf ist die Prognose nur gut, wenn eine frühzeitige antibiotische Therapie erfolgt. Methoden: Da konventionelle diagnostische Tests in diesem Lebensalter mit Problemen behaftet sind, eignen sich zur Identifizierung von infizierten vs. nichtinfizierten Neugeborenen vor allem standardisierte durchflusszytometrische Methoden, die mit minimalen Blutvolumina auskommen. Im Hinblick auf bakterielle Infektionen sind im durchflusszytometrischen Fokus Monozyten/Makrophagen, neutrophile Granulozyten und NK-Zellen. Ergebnisse: Bei Wahl der Parameter und der Interpretation der Kinetiken ist zu berücksichtigen, dass sich Rezeptordichte und die Fähigkeit zur zytokingetriggerten Hoch- und Herabregulation von Rezeptorexpressionen von termingerecht geborenen Babys, besonders aber von Frühgeborenen, und Erwachsenen erheblich unterscheiden können, wie dies z.B. für HLA-DR, CD80, CD86, CD32 und CD16 gezeigt wurde. In ersten größeren klinischen Studien haben sich die CD11b- und CD64-Expression auf neutrophilen Granulozyten in Kombination mit Plasma- oder Vollblut-Zytokin(IL-6 oder IL-8) oder -CRP(C-reaktives Protein)-Messungen als die durchflusszytometrischen Parameter mit der höchsten Sensitivität und Spezifität bei der frühen und späten Sepsis des Neugeborenenalters erwiesen. Schlussfolgerung: Es existiert momentan weder ein einzelner Parameter noch ein Panel davon, das es beim klinischen Verdacht auf eine Sepsis rechtfertigen würde, dem Kind eine antibiotische Behandlung zu verwehren.

\begin{tabular}{ll}
\hline KARGER & @ 2007 S. Karger GmbH, Freiburg \\
Fax +49 7614520714 & Accessible online at: \\
$\begin{array}{l}\text { E-mail Information@Karger.de } \\
\text { www.karger.com }\end{array}$ & www.karger.com/tmh
\end{tabular}

PD Dr. Thorsten W. Orlikowsky

Department of Neonatology, University Children's Hospital, University of Tübingen Calwer Straße 7, 72070 Tübingen, Germany

Tel. +49 7071 29-80878, Fax -4446

E-mail thorsten.orlikowsky@med.uni-tuebingen.de 


\section{Demand for Flow Cytometric Technique in Neonatology}

Flow cytometric analysis [1] of fetal umbilical cord blood [2] or blood from newborns and children [3, 4] have gained an important role in the diagnosis of a variety of physiologic and pathologic conditions in this early stage of life. Analysis of fetal hemoglobin for detection of fetomaternal hemorrhage is an accurate and widely used diagnostic procedure for investigation of anemia in fetuses and newborns [5]. Whole blood flow cytometry for the assessment of platelet function is particularly advantageous for neonatal studies because only minuscule blood volumes are required [6, 7]. Cord blood is an effective source of stem cells for allogeneic stem cell transplantation $[8,9]$. It has several advantages over other stem cell sources, including ease and safety of procurement, rapid availability, no donor attrition, limitless supply, decreased viral transmission, reduced severe acute and chronic graft-versushost disease. A diagnostic renaissance of flow cytometric methods occurred in the 1990s with better characterization of cord blood subsets [reviewed in 10]. The fastest growing indication for flow cytometric methods in neonatology, however, is the detection of bacterial infection. Flow cytometry has some important features for neonatal diagnostics: requirement of minimal sample volume, high acquisition speed and measurement of multiple parameters on the same cell (multiplexing, cytomics analysis) [11, 12]. The aim of this review therefore is to summarize the most recent developments in neonatal sepsis detection by flow cytometry.

\section{Role of Flow Cytometry in the Detection of Infection}

Despite advances in management, both early- and late-onset forms of infection remain the main causes of neonatal morbidity and mortality worldwide. Approximately $25 \%$ of preterm neonates suffer at least one episode of late-onset sepsis [13], with higher probability of developing chronic lung disease and adverse sequelae, e.g. neurodevelopmental or gastrointestinal complications [14]. Early clinical features of infection are subtle, non-specific and difficult to recognize [15]. Furthermore, non-infected newborns such as those with transient tachypnea are clinically indistinguishable from those in an initial infectious stage [15]. With clinical signs unspecific and little, its course yet is fulminant, and only early antibiotic therapy has been shown to protect newborns [6].

With increasing understanding of the inflammatory sepsis cascade and advances in diagnostic technologies, many potential infection markers have been investigated [16]. The use of flow cytometric methods in clinical neonatology is extremely helpful since the benefit of conventional 'classic' hematologic and serologic tests to differentiate between infected and non-infected newborns is limited for several reasons:

- The total white blood cell count (WBC), a historic marker of infection, exhibits a wide range of normality and is influ- enced by perinatal confounders, e.g. duration of labor [reviewed in 17].

- Automated neutrophil quantification methods may be inaccurate in the presence of nucleated red blood cells, often present in the preterm neonate.

- The assessment of neutrophil band and metamyelocytic forms to determine the immature:total ratio ( $\mathrm{I} / \mathrm{T}$ ratio) is subjective and depends upon experience and definition of the hematologist.

- Since even uncomplicated labor (from a reductionistic immunological view) is an inflammatory event, most serologic parameters, e.g. chemokines, cytokines or acute phase proteins, are elevated non-specifically in the first hours of life or they follow specific postnatal time kinetics [18].

- Although soluble factors are promising diagnostic markers for the detection of infection, their measurement with enzyme-linked immunosorbent assay (ELISA) is usually performed in batches which may translate to delays in the reporting.

As circulating cytokine concentrations may not necessarily reflect biological activities at the cellular level, quantifying cellular response may be a more accurate way of identifying the functional status of responder cells and more closely reflect host inflammatory activity $[15,19,20]$. With qualified personal available and thorough standardization protocols, the detection of cell surface antigens by flow cytometric technique permits simultaneous quantitative measurement of a receptor panel, identified upon specific cell types or subsets, with a small blood volume (e.g. $50 \mu \mathrm{l}$ - approximately one drop of blood) on an ad-hoc basis and with a turnaround time of $2 \mathrm{~h}$. Hence, there is much interest in quantifiable markers that can reliably differentiate between infected and non-infected neonates. Cells in the focus of interest are monocytes, monocyte-derived macrophages (MФ), neutrophils, T cells, and NK cells. To date, published reports on flow cytometric technique in infected newborns still are limited but recommendable reviews recently have been published $[15,17,21]$.

\section{Quantitative and Qualitative Features of Effector Cells in Neonatal Sepsis}

Receptor Densities, Perinatal Co-Factors and Gestational Age A variety of receptors on effector cells for neonatal sepsis differ between neonates and adults in basal surface densities and in their capacity to up- or down-regulate them upon stimulation so that adult reference values or ranges cannot be applied (table 1) [3,22]. For several reasons one should be careful with present studies: Many studies, including our own, use cord blood as a source of neonatal immune cells for comparing neonatal immune response to those of adults. Since most investigators have not longitudinally measured kinetics of cord and peripheral blood of newborns, this model may not properly reflect the situation several days postnatally. Further- 
Table 1. Comparison of phenotypic and functional differences between immune cells, targeted by flow cytometric methods for neonatal infection

\begin{tabular}{|c|c|c|c|}
\hline Parameter/function & Detection system & $\begin{array}{l}\text { Cord/neonatal blood } \\
\text { vs. peripheral blood } \\
\text { of adults }\end{array}$ & Reference \\
\hline CD64 on granulocytes & $\begin{array}{l}\text { phenotype by flow cytometry } \\
\text { comparison: basal and infected/non-infected }\end{array}$ & $=$ & $34,35,41$ \\
\hline $\begin{array}{l}\text { CD11b on granulocyes/ } \\
\text { monocytes }\end{array}$ & $\begin{array}{l}\text { phenotype by flow cytometry } \\
\text { comparison: basal and infected/non-infected }\end{array}$ & $=$ & $40,38,39$ \\
\hline HLA-DR on monocytes & $\begin{array}{l}\text { phenotype by flow cytometry } \\
\text { comparison: basal and infected/non-infected }\end{array}$ & $\nabla$ & $25,26,42,43$ \\
\hline TLR2/TLR4 on monocytes & $\begin{array}{l}\text { Phenotype by flow cytometry } \\
\text { comparison: basal and infected/non-infected }\end{array}$ & $\boldsymbol{\nabla}$ (unstimulated) & 32,33 \\
\hline $\begin{array}{l}\text { Monocyte co-stimulation: } \\
\text { phenotype/function }\end{array}$ & $\begin{array}{l}\text { CD80, CD86, HLA-DR expression } \\
\text { monocyte-dependent } \mathrm{T} \text { cell stimulation with anti-CD3 }\end{array}$ & $\boldsymbol{\nabla}$ & 23,27 \\
\hline IFN- $\gamma$ production & $\begin{array}{l}\text { basal production / after stimulation (ELISA), mRNA } \\
\text { production, intracellular concentration (FACS) }\end{array}$ & $\boldsymbol{\nabla}$ & 27 \\
\hline Monocyte sensitivity for IFN- $\gamma$ & $\begin{array}{l}\text { phenotype by flow cytometry } \\
\text { polyclonal T cell stimulation }\end{array}$ & $\nabla$ & 27 \\
\hline $\begin{array}{l}\text { Monocyte cytotoxicity: } \\
\text { phenotype/function }\end{array}$ & $\begin{array}{l}\text { CD16, (CD 95L) expression } \\
\text { ADCC with anti-CD4 monoclonal antibody / immune complexes }\end{array}$ & $\boldsymbol{\nabla}$ & 28 \\
\hline $\begin{array}{l}\text { IL-10 production and } \\
\text { sensitivity for IL-10 }\end{array}$ & $\begin{array}{l}\text { basal expression, stimulation (LPS, OKT3) } \\
\text { mRNA production, intracellular stain, protein production }\end{array}$ & $\boldsymbol{\nabla}$ & 28,47 \\
\hline Immunparalysis by steroids & $\begin{array}{l}\text { phenotype by flow cytometry } \\
\text { T cell stimulation with polyclonal stimuli }\end{array}$ & $\boldsymbol{\Delta}$ & 23 \\
\hline $\begin{array}{l}\text { Effect of phosphatidylcholine } \\
\text { species }\end{array}$ & co-culture with surfactant-specific phosphatidylcholine species & $\boldsymbol{\nabla} \boldsymbol{\Delta}$ & 60 \\
\hline Phagocytic activity against $E$. coli & incubation with gfp-labelled bacteria, kinetics & $=$ & 30 \\
\hline Intracellular killing of E. coli & plating experiments with gfp-labelled bacteria & $=$ & 30 \\
\hline $\begin{array}{l}\text { Induction of apoptosis by } \\
\text { Immunoglobulins }\end{array}$ & detection of $\mathrm{M} \Phi$ apoptosis by annexin $\mathrm{V}$ & $\boldsymbol{\Delta}$ & 61 \\
\hline
\end{tabular}

$\boldsymbol{\nabla}$ = Reduced phenotypic expression, function, or sensitivity of cord/neonatal blood vs. adult blood.

$\boldsymbol{\Delta}$ = Enhanced phenotypic expression, function, or sensitivity of cord/neonatal blood vs. adult blood.

$==$ No difference in phenotype, function, or sensitivity.

$\mathrm{CB} / \mathrm{NB}=$ Cord $/$ neonatal blood $\mathrm{PB}=$ adult peripheral blood; $\mathrm{TLR}=$ Toll-like rerceptor.

more, since in clinical practice the group of preterm neonates in studies is heterogeneous (there is no 'physiological preterm labor'), one cannot rule out effects, e.g. of multiparous pregnancy, treatment of the mother with antibiotics or steroids, on their immunological profile. To examine these parameters as well as inter-individual variations, further studies are required. A broad spectrum of variables, e.g. duration and mode of delivery, exist [17], and gestational age as a part of the fetus' immaturity may play an important role in leukocyte cell surface marker densities. Therefore, the measurement and quantification of HLA-DR, B7-family receptor densities on monocytes and their reaction upon cytokine stimulation turned out to become difficult in clinical settings [23, 24]. HLA-DR, a major histocompatibility class II complex, is one of the key cell surface molecules expressed on monocytes and is responsible for antigen presentation to $\mathrm{T}$ cells and initiation of the inflammatory cascade during infection [15]. HLA-DR expression on monocytes was found significantly decreased in adult patients who developed sepsis after trauma or major surgery compared to uncomplicated patients $[15,25]$. This feature theoretically assists in distinguishing infected newborns from those with only physical trauma, e.g. cephalic hematoma. We [23] and others [26] have shown HLA-DR expression of term and preterm newborns to be lower compared to adults during the first day of life. Prematurity correlated with lower expression, with gestational age less than 32 weeks. HLA-DR expression in neonates with signs of infection was decreased compared to healthy neonates [26]. Although maternal conditions (preeclampsia, prenatal treatment with steroids and mode of delivery) had no influence on the HLA-DR expression, newborns with respiratory distress syndrome but without signs of infection showed reduced densities.

\section{Co-Stimulatory Potential of Monocytes/M $\Phi$}

$\mathrm{M} \Phi$ receptors of the $\mathrm{B} 7$ family $(\mathrm{CD} 80, \mathrm{CD} 86)$ which are triggered after infections play an important role in $\mathrm{T}$ cell activa- 
tion: The lack of co-stimulation via B7 molecules may lead to anergy or apoptosis of reactive T cells. IFN- $\gamma$ generates a costimulatory helper $\mathrm{M} \Phi$ type $(\mathrm{Mh})$ which expresses and up-regulates B7 family receptors (CD80, B7-1 and CD86, B7-2. Its engagement of T cell CD28 family molecules influences T cell survival and activation as well as $\mathrm{TH} 1 / \mathrm{TH} 2$ cytokine production, processes which are crucial in the crosstalk between innate and adaptive immunity. As compared to $М \Phi$ from adults, M $\Phi$ from cord blood or neonates show decreased basal expression and capacity to up-regulate CD80 and/or CD86 upon challenge with a variety of stimulants which act upon different signal transduction cascades [27]. If one would like to quantify the co-stimulatory $\mathrm{M} \Phi$ potential by flow cytometry as determined by IFN- $\gamma$ stimulation, e.g. as a predictor or prognostic factor of immune responses, therefore would require separate reference value systems in neonates [27].

\section{Cytotoxic Potential of Monocytes/MФ}

An antagonistic cytokine to IFN- $\gamma$, IL-10 induces a cytotoxic MФ type (Mc) which fails to up-regulate HLA-DR and B7 molecules and is prone to apoptosis, another important feature of septic reactions. Mc-MФ are mediators to destroy cells by antibody-dependent cellular cytotoxicity (ADCC) [28, 29]. Neonatal MФ were found impaired to generate Mc-MФ [28]. As targets for flow cytometry in sepsis, the measurement of both the co-stimulatory and cytotoxic potential of neonatal M $\Phi$ after cytokine induction would bear intrinsic problems due to a hyporesponsiveness towards cytokines [23, 27, 28].

\section{Phagocytic Potential of Monocytes/M $\Phi$}

Although neonatal M $\Phi$ exhibit deficiencies in adaptive immune functions, their phagocytic capacity in response to Escherichia coli, a most dangerous inducer of infection, in noninfected newborns was shown to be comparable to that of $\mathrm{M \Phi}$ of adults [30]. Since this flow cytometric test is fast, simple and only requires $50 \mu \mathrm{l}$ of whole blood, its longitudinal measurement may serve as a functional test and is currently under investigation.

\section{Expression of Toll-Like Receptors}

The reason for differences in the course of neonatal and adult sepsis include molecular mechanisms like recognition of microbes by Toll-like receptors (TLR) for the initiation, perpetuation and termination to systemic inflammatory response [31]. TLR2 was identified as a receptor for Gram-positive peptidoglycan and bacterial lipopeptides, whereas TLR4 recognizes Gram-negative bacterial lipopolysaccharides (LPS) and is required for inflammatory signal transduction. TLR2 and TLR4 expressions on monocytes and granulocytes of healthy neonates were analyzed in mononuclear cells by flow cytometry and compared to those of healthy adults: Basal TLR2 expression was only slightly lower in neonatal phagocytes, whereas no differences could be detected for TLR4. Analyzing septic neonates, there was a significant up-regulation of
TLR2 on blood phagocytes already at initial presentation of symptoms. Comparison with C-reactive protein (CRP), IL-8, and IL- 6 suggested that TLR2 expression on monocytes was comparably valuable as an early sepsis marker. TLR2 was differentially regulated during neonatal sepsis, showing a constant up-regulation on monocytes but only a transient increase on granulocytes [32]. This study revealed a mild deficiency of TLR2 expression in newborns and demonstrated a differential expression of TLR2, but not TLR4, in the course of neonatal sepsis, which could reflect specific inflammatory responses to distinct pathogens. Although TLR4 expression was unchanged during sepsis [32], Forster-Waldl et al. [33] showed TLR4 expression to be correlated to gestational age. The definition of TLR expression patterns might open a new field of therapeutic targets for neonatal sepsis [32].

\section{Clinical Studies on Cellular Targets in Neonatal Infection}

Cell surface antigens that have been studied by flow cytometry in recent years with respect to congenital, early- and lateonset sepsis include CD11b, Fc $\gamma$ receptors I-III (CD64, CD32, CD16), and CD69 [34-37]. Blood specimens for cell surface markers should be transported to the laboratory on ice and processed immediately: Studies showed that a substantial proportion of neutrophils undergoes apoptosis after $24 \mathrm{~h}$ and down-regulates surface receptor antigens during the apoptotic process [36, 37]. Therefore, analysis of neutrophil surface antigens should be performed immediately so that pre-analytic conditions (temperature, time, continuous activation of inflammatory cells in vitro, $\mathrm{pH}$ ) should not affect receptor expression levels [21].

\section{CD11b/CD18 Expression}

$\mathrm{CD} 11 \mathrm{~b}$ is a subunit of a $\beta 2$ integrin adhesion molecule, expressed at very low concentrations on the surface of non-activated neutrophils. As it can be expressed without de novo protein synthesis, receptor densities increase considerably within minutes after contact between inflammatory cell and bacteria, bacterial products and/or endotoxins [36]. These unique characteristics enable CD11b to be used as an early marker of bacterial infection. Although previous trials were unable to demonstrate its diagnostic value for prediction of late-onset infection in preterm infants [35]. However, a recent study suggested that increased expression of neutrophil or monocyte CD11b/CD18 detected by repeated measurements can identify cases before the arousal of clinical suspicion [37]. In this study, CD11b expression gradually increased in preterm infants during the 3 days prior to sampling of blood cultures. The sensitivity and specificity of CD11b was 100 and 56\% for neutrophils and 86 and $94 \%$ for monocytes, respectively [37], but other study results show a variability [35-39]. This discrepancy is related to pre-analytic differences, evaluation of different populations, criteria for sepsis, time points of test per- 
forming, and standardization of the flow cytometric technique. $\mathrm{CD} 11 \mathrm{~b}$ expression is influenced by non-infective conditions such as respiratory distress syndrome and common neonatal procedures. Turunen et al. [40] showed neutrophil CD11b expression to increase in ventilated infants from birth to $24 \mathrm{~h}$ of age, whereas non-ventilated neonates showed no significant increase. In preterm neonates with respiratory distress syndrome, significant activation of circulating phagocytes occurred within $3 \mathrm{~h}$ of the onset of mechanical ventilation, independent of surfactant administration, which suggested mechanical ventilation to be an inducer of this inflammatory response. Further largerscale studies are needed to address these concerns and to generate robust data to support the conclusions.

\section{CD64 Expression}

$\mathrm{Fc} \gamma$ receptor 1 (CD64) is involved in phagocytosis of bacteria and their intracellular degradation; normally it is expressed in low concentrations by unstimulated neutrophils and monocytes/M $\Phi$ but up-regulated on the trigger of bacterial invasion [34]. In contrast to markers discussed above (table 1), neutrophils from preterm neonates express CD64 to the same degree as those from term infants, children and adults during bacterial infections [15, 34]. Neutrophils from preterm infants showed moderately increased CD64 expression during their first month of life, which dropped in their first month of life to levels of term neonates, infants and adults [41]. In contrast, levels of neutrophil expression of Fc $\gamma$ receptors II and III (CD32 and CD16) were significantly lower in preterm than term infants and adults [41]. Neutrophils from all groups indicated similar levels of CD11b expression [41]. CD64 expression was influenced by bacterial infection but was unaffected by respiratory distress syndrome, premature rupture of membranes or other factors related to preterm. CD64 increase in response to bacterial infection in preterm and term infants was similar in magnitude compared to older children and adults, suggesting it to be a useful marker in neonatal infections [15, 21, 34, 35].

Amongst four cell surface markers (two neutrophil markers CD11b and CD64, and two lymphocyte markers - CD25 and CD45RO), CD64 had the highest sensitivity (95-97\%) and specificity $(88-90 \%)$ at the onset and up to $24 \mathrm{~h}$ after the initial clinical presentation for diagnosing late-onset bacterial infection [35]. The concomitant use of neutrophil CD64 and IL6 or CRP further improved the sensitivity to $100 \%$ [35]. Similarly, a large cohort study demonstrated that neutrophil CD64 was substantially up-regulated and useful (sensitivity $96 \%$ and specificity $81 \%$ ) for identifying term newborn infants with early-onset clinical sepsis and pneumonia [34]. The relatively wide diagnostic window (0-24 h) of CD64 up-regulation adds to its clinical usefulness.

\section{HLA-DR Expression}

Hallwirth et al. [42] found that infected preterm neonates had lower HLA-DR expression on the 3rd day of life than non-in- fected. A study of term newborns with suspected early-onset infections $(\mathrm{n}=288)$, however, was disappointing [43]: There were no significant differences in monocyte HLA-DR expression between infected, non-infected and control groups at $0 \mathrm{~h}$ and between infected and non-infected newborns at $24 \mathrm{~h}$. The areas under the receiver operating characteristics (ROC) curves for HLA-DR, CD64 and CRP were 0.52-0.54, $0.88-0.94$ and $0.75-0.77$, respectively. The investigators were unable to determine an optimal cut-off value for HLA-DR, as the diagnostic utilities of any cut-off point on the ROC curves were unable to satisfy the criteria (i.e. sensitivity and specificity $>80 \%$ ) for consideration as an useful diagnostic marker [43].

\section{Expression of Surface Markers on NK and T Cells}

Other surface markers of diagnostic relevance include CD69 on NK cells and CD69, CD45RA, CD45RO and CD25 on peripheral T lymphocytes [36, 44]. NK cell CD69 was a sensitive marker for diagnosing neonatal infection, correctly identifying 13 of 16 infants with septicemia [15, 36]. CD69 expression on NK cells together with CD45RA, CD45RO, CD25 and CD69 expression on $\mathrm{T}$ cells indicated that in infected infants, there were significant increases in at least two of the inflammatory mediators [36, 44]. A recent study [34], including a large cohort of very low birthweight infants, was unable to confirm the usefulness of lymphocyte CD45RO and CD25 for diagnosing late-onset bacterial infection. CD45RO, a memory antigen for T lymphocytes, is more useful in detecting congenital viral infections. Its prolonged expression for several weeks or months after exposure to infections renders it unsuitable for use in the neonatal intensive care unit [21]. Weinschenk et al. [39] have studied a panel of lymphocyte (CD3, CD19, CD25, CD26, CD71 and CD69) and neutrophil surface antigens (CD11b, CD11c, CD13, CD15, CD33 and CD66b) and found that leukocytes of preterm newborns responded to infection with an increased expression of CD19, CD33, and CD66b. However, the diagnostic utilities of these markers in infection are not known and further studies are required.

\section{Cytokines and Combinations}

Pro- and anti-inflammatory cytokines such as IL-6, IL-8, IL10 , IFN- $\gamma$, and TNF- $\alpha$ have been shown to be up-regulated during neonatal sepsis [45-48]. IL-6 and IL-8 increase rapidly after exposure to bacterial products [15] and precede the increase in CRP $[15,21,48]$. Cord blood IL-6 is a sensitive marker (sensitivity $87-100 \%$ and negative predictive value 93-100\%) for diagnosing early-onset neonatal infection [15]. IL-6 and IL-8 have very short half-lives, and circulating concentrations drop precipitously following antimicrobial treatment, becoming undetectable within $24 \mathrm{~h}[45,48]$. The window of opportunity for IL-6 to detect infection is narrow; and therefore it should be used in conjunction with a 'late' and more specific marker such as CRP to improve its diagnostic capability in clinical practice [45]. In order to improve the sen- 
sitivity and specificity of IL-8, we developed a detergent-lysed whole blood assay [48], showing IL-8 concentrations to be sustained for more than $24 \mathrm{~h}$ and thus hopefully present neonatologists a wider window of opportunity for obtaining a blood sample. The automated system used by the investigators required only $50 \mu \mathrm{l}$ of blood and $50 \mathrm{~min}$ to process the specimens [48].

\section{Conclusions}

As recognized before [15, 21], flow cytometric markers for neonatal infection possess intrinsic clinical and laboratory characteristics. Selection of a panel of markers with different features can improve diagnostic utilities, increase the window of detection, and provide prognostic information for the underlying condition [15]. It is important to standardize the methodology of assessing new diagnostic markers [49] and to clarify the definition of neonatal sepsis [17, 49].

Recent developments in microscopic imaging provide the hope that very soon also microscope-based cytometry instru- ments (slide-based cytometers) will become commercially available. These instruments have features that can even surpass flow cytometry by minimizing required sample volume by one order of magnitude [50] and increasing the number of simultaneously analyzable parameters per cell [51, 52]. Based on increased multiplexing, high-content analysis of cell populations becomes available [53] that would increase our understanding of infection development and may lead to predictive medicine [54-56] for preventive therapy [57-59].

To date, no flow cytometric marker or set of markers is sensitive and specific enough to allow neonatologists to withhold antibiotic treatment of a sick infant who is suspected to be seriously infected. The use of reliable markers, including neutrophil CD64, CD11b, IL-6, IL-8, either singly or in combination with an acute phase protein [21, 34, 38, 48] could help clinicians in deciding to terminate antibiotics early in non-infected neonates. It is feasible to custom-make a panel of reliable and clinically useful infection markers for flow cytometric analysis. This technology is likely to become an essential and integral part of routine laboratory investigations in the future.

\section{References}

1 Schlenke P: Leukocyte reduction in blood component supply: The impact of flow cytometry in assessing residual leukocytes. Transfus Med Hemother 2005;32(1):12-19.

$\checkmark 2$ Kamprad M, Kindler S, Schuetze N, Emmrich F: Flow cytometric immunophenotyping of umbilical cord and peripheral blood haematopoietic progenitor cells by different CD34 epitopes, CD133, P-glycoprotein expression and Rhodamine-123 efflux. Transfus Med Hemother 2007;34(3):195-203.

3 Sack U, Fee, Tárnok A: Age related lymphocyte subset changes in the peripheral blood of healthy children - a meta-study. Transfus Med Hemother 2007;34(3):176-181.

4 Bocsi J, Lenz D, Sauer U, Wild L, Hess J, Schneider P, Hambsch J, Schranz D, Tárnok A: Inflammation and immune suppression following protein losing enteropathy after Fontan surgery detected by cytomics. Transfus Med Hemother 2007;34(3): 168-175.

5 Dziegiel MH, Nielsen LK, Berkowicz A: Detecting fetomaternal hemorrhage by flow cytometry. Curr Opin Hematol 2006;13:490-495.

$\checkmark 6$ Michelson AD: Platelet function in the newborn. Semin Thromb Hemost 1998;24:507-512.

7 Socher I, Kroll H, Santoso S: Heterogeneity of platelet alloantigens and alloantibodies: New insights into structure and function. Transfus Med Hemother 2006;33(3):244-253.

8 Eichler H, Burkhart J, Sputtek A, Wiesneth M: Statement of the section 'Transplantation and cellular therapy' of the DGTI from August 15, 2005: Extraction and long time storage of autologous and allogenous stem cells samples from cord blood - indications and limits. Transfus Med Hemother 2005;32(5):274-282.
-9 McGuckin CP, Forraz N, Baradez MO, Navran S, Zhao J, Urban R, Tilton R, Denner L: Production of stem cells with embryonic characteristics from human umbilical cord blood. Cell Prolif 2005;38(4): 245-55.

10 Korbling M, Anderlini P: Peripheral blood stem cell versus bone marrow allotransplantation: does the source of hematopoietic stem cells matter? Blood 2001;98:2900-2908.

11 Tárnok A, Bocsi J, Brockhoff G: Cytomics - importance of multimodal analysis of cell function and proliferation in oncology. Cell Prolif 2006;39(6): 495-505.

12 Lambert C, Cristina I, Christian G: Enumeration of peripheral lymphocyte subsets using 6 vs. 4 color staining: a clinical evaluation of a new flow cytometer. Cytometry B Clin Cytom 2006;70B(1):29-38.

13 Stoll BJ, Hansen NI, Adams-Chapman I, Fanaroff AA, Hintz SR, Vohr B, Higgins RD; National Institute of Child Health and Human Development Neonatal Research Network: Neurodevelopmental and growth impairment among extremely lowbirth-weight infants with neonatal infection. JAMA 2004:292:2357-2365.

14 Stoll BJ, Hansen N, Fanaroff AA, Wright LL, Carlo WA, Ehrenkranz RA, Lemons JA, Donovan EF, Stark AR, Tyson JE, Oh W, Bauer CR, Korones SB, Shankaran S, Laptook AR, Stevenson DK, Papile LA, Poole WK: Late-onset sepsis in very low birth weight neonates: the experience of the NICHD Neonatal Research Network. Pediatrics 2002;110:285-291.

$15 \mathrm{Ng}$ PC: Diagnostic markers of infection in neonates. A comprehensive review summarizing the evolution of infection markers in neonatology over the past two decades. Arch Dis Child Fetal Neonatal Ed 2004;89:F229-F235.
16 Sbrana S, Bevilacqua S, Buffa M, Spiller D, Parri MS, Gianetti J, De Filippis R, Clerico A: Postreperfusion changes of monocyte function in coronary blood after extracorporeal circulation. Cytometry B Clin Cytom 2005;65B(1):14-21.

17 Chiesa C, Panero A, Osborn JF, Simonetti AF, Pacifico L: Diagnosis of neonatal sepsis: a clinical and laboratory challenge. Clin Chem 2004;50: 279-287.

18 Orlikowsky TW, Trug C, Neunhoeffer F, Deperschmidt M, Eichner M, Poets CF: Lipopolysaccharide-binding protein in noninfected neonates and those with suspected early-onset bacterial infection. J Perinatol 2006;26(2):115-9.

19 Barten JB, Gummert JF: Biomarkers in transplantation medicine: prediction of pharmacodynamic drug effects. Transfus Med Hemother 2007;34(3): 182-187.

20 Bocsi J, Richter M, Hambsch J, Barten MJ, Dahnert I, Schneider P, Tárnok A: Transient Th1/Th2 disbalance indicates postoperative effusions and edema after cardiopulmonary bypass in children. Cytometry A 2006;69A(3):165-8.

21 Ng PC, Lam HS: Diagnostic markers for neonatal sepsis. Curr Opin Pediatr 2006;18:125-131.

22 Tárnok A, Bocsi J, Lenz D, Janousek J: Protein losing enteropathy (PLE) after Fontan surgery - clinical and diagnostical aspects. Transfus Med Hemother 2007;34(3):164-167.

23 Orlikowsky TW, Dannecker GE, Spring B, Hoffmann MK, Poets CF: Effect of dexamethasone on B7-regulation and $\mathrm{T}$ cell activation in neonates and adults. Pediatr Res 2005;57:656-661.

24 Hallwirth U, Pomberger G, Pollak A, Roth E, Spittler A: Monocyte switch in neonates: high phagocytic capacity and low HLA-DR expression in VLBWI are inverted during gestational aging. Pediatr Allergy Immunol 2004;15(6):513-6. 
25 Lekkou A, Karakantza M, Mouzaki A, Kalfarentzos F, Gogos CA: Cytokine production and monocyte HLA-DR expression as predictors of outcome for patients with community-acquired severe infections. Clin Diagn Lab Immunol 2004;11:161-167.

-26 Birle A, Neber CT, Gessler P: Age-related low expression of HLA-DR molecules on monocytes of term and preterm newborns with and without signs of infection. J Perinatol 2003;23:294-299.

27 Orlikowsky TW, Spring B, Dannecker GE, Niethammer D, Poets CF, Hoffmann MK: Expression and regulation of $\mathrm{B} 7$ family molecules on macrophages in preterm and term neonatal cord blood and peripheral blood of adults. Cytometry B Clin Cytom 2003;53B:40-47.

28 Gille C, Spring B, Tewes LJ, Löffler J, Dannecker GE, Hoffmann MK, Poets CF, Orlikowsky TW: Reduced antibody-dependent cellular cytotoxicity (ADCC) of cord blood macrophages (CBMФ) and diminished response to interleukin-10 (IL-10). Pediatr Res 2006;60:152-157.

-29 Bocsi J, Richter M, Hambsch J, Barten M J, Dähnert I, Schneider P, Tárnok A: Transient Th1/Th2 shift after cardiopulmonary bypass in children. $\mathrm{Cy}$ tometry A 2006;69A:165-8.

30 Gille C, Spring B, Tewes L, Poets CF, Orlikowsky TW: A new method to quantify phagocytosis and intracellular degradation using green fluorescent protein-labelled Escherichia coli: Comparison of cord blood macrophages and peripheral blood macrophages of healthy adults. Cytometry A 2006; 69A:152-154.

-31 Sadeghi K, Berger A, Langgartner M, Prusa AR, Hayde M, Herkner K, Pollak A, Spittler A, ForsterWaldl E: Immaturity of infection control in preterm and term newborns is associated with impaired tolllike receptor signaling. J Infect Dis 2007;195(2): 296-302.

-32 Viemann D, Dubbel G, Schleifenbaum S, Harms E, Sorg C, Roth J: Expression of toll-like receptors in neonatal sepsis. Pediatr Res 2005;58:654-459.

33 Forster-Waldl E, Sadeghi K, Tamandl D, Gerhold B, Hallwirth U, Rohrmeister K, Hayde M, Prusa AR, Herkner K, Boltz-Nitulescu G, Pollak A, Spittler A: Monocyte toll-like receptor 4 expression and LPS-induced cytokine production increase during gestational aging. Pediatr Res 2005;58:121-124.

\$3 Ng PC, Li G, Chui KM, Chu WC, Li K, Wong RP, Chik KW, Wong E, Fok TF: Neutrophil CD64 is a sensitive diagnostic marker for early-onset neonatal infection. Pediatr Res 2004;56:796-803.

>35 Ng PC, Li K, Wong RP, Chui KM, Wong E, Fok TF: Neutrophil CD64 expression: a sensitive diagnostic marker for late-onset nosocomial infection in very low birthweight infants. Pediatr Res 2002;51: 296-303.
36 Hodge G, Hodge S, Han P, Haslam R: Multiple leucocyte activation markers to detect neonatal infection. Clin Exp Immunol 2004;135:125-129.

37 Turunen R, Andersson S, Nupponen I, Kautiainen $\mathrm{H}$, Siitonen S, Repo H: Increased CD11b-density on circulating phagocytes as an early sign of lateonset sepsis in extremely low-birth-weight infants. Pediatr Res 2005;57:270-275.

38 Nupponen I, Andersson S, Jarvenpaa AL, Kautiainen H, Repo H: Neutrophil CD11b expression and circulating interleukin- 8 as diagnostic markers for early-onset neonatal sepsis. Pediatrics 2001;108: E12.

39 Weinschenk NP, Farina A, Bianchi DW: Premature infants respond to early-onset and late-onset sepsis with leukocyte activation. J Pediatr 2000;137: 345-350.

40 Turunen R, Nupponen I, Siitonen S, Repo H, Andersson S: Onset of mechanical ventilation is associated with rapid activation of circulating phagocytes in preterm infants. Pediatrics 2006;117: 448-454.

41 Fjaertoft G, Hakansson L, Foucard T, Ewald U, Venge P: CD64 (Fcgamma receptor I) cell surface expression on maturing neutrophils from preterm and term newborn infants. Acta Paediatr 2005;94: 295-302.

42 Hallwirth U, Pomberger G, Zaknun D, Szepfalusi Z, Horcher E, Pollak A, Roth E, Spittler A: Monocyte phagocytosis as a reliable parameter for predicting early-onset sepsis in very low birthweight infants. Early Hum Dev 2002;67:1-9.

$43 \mathrm{Ng}$ PC, Li G, Chui KM, Chu WC, Li K, Wong RP, Fok TF: Quantitative measurement of monocyte HLA-DR expression in the identification of earlyonset neonatal infection. Biol Neonate 2005;89: $75-81$

44 Hodge S, Hodge G, Flower R, Han P: Surface activation markers of $\mathrm{T}$ lymphocytes: role in the detection of infection in neonates. Clin Exp Immunol 1998;113:33-38.

$45 \mathrm{Ng}$ PC, Cheng SH, Chui KM, Fok TF, Wong MY, Wong W, Wong RP, Cheung KL: Diagnosis of late onset neonatal sepsis with cytokines, adhesion molecule, and C-reactive protein in preterm very low birthweight infants. Arch Dis Child Fetal Neonatal Ed 1997;77:F221-F227.

46 Ng PC, Li K, Wong RP, Chui K, Wong E, Li G, Fok TF: Proinflammatory and anti-inflammatory cytokine responses in preterm infants with systemic infections. Arch Dis Child Fetal Neonatal Ed 2003; 88:F209-F213.

47 Schultz C, Temming P, Bucsky P, Gopel W, Strunk T, Hartel C: Immature anti-inflammatory response in neonates. Clin Exp Immunol 2004;135:130-136.
48 Orlikowsky TW, Neunhoeffer F, Goelz R, Eichner M, Henkel C, Zwirner M, Poets CF: Evaluation of IL-8-concentrations in plasma and lysed EDTAblood in healthy neonates and those with suspected early onset bacterial infection. Pediatr Res 2004;56: 804-809.

$49 \mathrm{Ng}$ PC: Clinical trials for evaluating diagnostic markers of infection in neonates. Biol Neonate 2005;87:111-112.

50 Laffers W, Schlenkhoff C, Pieper K, Mittag A, Tárnok A, Gerstner AOH: Concepts for absolute immunophenosubtyping by slide-based cytometry. Transfus Med Hemother 2007;34(3):188-194.

51 Mittag A, Lenz D, Gerstner AO, Tárnok A: Hyperchromatic cytometry principles for cytomics using slide based cytometry. Cytometry A 2006;69A(7): 691-703.

52 Tarnok A: Slide-based cytometry for cytomics - a minireview. Cytometry A 2006;69A:555-62.

53 Barten MJ, Rahmel A, Bocsi J, Boldt A, Garbade J, Dhein S, Mohr FW, Gummert JF: Cytokine analysis to predict immunosuppresion. Cytometry A 2006; 69A:155-7.

54 Bocsi J, Mittag A, Sack U, Gerstner AO, Barten MJ, Tárnok A: Novel aspects of systems biology and clinical cytomics. Cytometry A 2006;69A(3): $105-8$.

55 Tárnok A, Valet GK, Emmrich F: Systems biology and clinical cytomics: The 10th Leipziger Workshop and the 3rd International Workshop on SlideBased Cytometry, Leipzig, Germany, April 2005. Cytometry A 2006;69A(1):36-40.

56 Valet G: Human cytome project, cytomics, and systems biology: the incentive for new horizons in cytometry. Cytometry A 2005;64(1):1-2.

57 Boldt A, Barten MJ, Weiß C, Sagner A, Mohr FW, Gummert JF: Novel whole blood apoptosis assay to assess immunosuppression. Cytometry A 2006; 69A:158-60.

58 Barten MJ, Tárnok A, Garbade J, Bittner HB, Dhein S, Mohr FW, Gummert JF: Pharmacodynamics of T-cell functions for monitoring immunosuppression. Cell Prolif 2007;40:50-63.

59 Lenz D, Barten M J, Hiller S, Tárnok A: Regenerative and predictive medicine of cardiovascular disease: the 9th Leipziger Workshop and the 2nd International Workshop on Slide Based Cytometry. Cytometry A 2005;64A:110-114.

60 Gille C, Spring B, Bernhard W, Poets CF, Orlikowsky TW: Differential effect of surfactant and its saturated phosphatidylcholines on human blood macrophages. J Lipid Res 2007;48:307-317.

61 Gille C, Spring B, Dannecker GE, Hoffmann MK, Poets CF, Orlikowsky TW: Immunoglobulins alter phenotype and function of macrophages $(\mathrm{M} \Phi)$ and may induce cell death: A comparison of cord blood and peripheral blood of healthy adults. Cytometry B Clin Cytom 2007;(in press). 